\title{
HUBUNGAN DUKUNGAN KELUARGA DENGAN RESPON SOSIAL INDIVIDU \\ PASIEN HIV/AIDS DI WILAYAH KECAMATAN REJOSO \\ KABUPATEN NGANJUK
}

\author{
Titiek Endah Puspa Rini ${ }^{1}$, Cucuk Suwandi ${ }^{2}$, Sujatmiko ${ }^{3}$ \\ ${ }^{123}$ STIKes Satria Bhakti Nganjuk \\ Email : titiekendah79@gmail.com
}

\begin{abstract}
Introduction : HIV / AIDS patients tend to experience emotional stress as well as psychological stress related to the discrimination they receive so as to trigger changes in the patient's social response. Concern, family affection is one of the much needed support for people with HIV / AIDS. The purpose of this study to determine the correlation of family support with social response of HIV/AIDS patients in Rejoso District Nganjuk City. Method: The design of this research is correlation with cross sectional approach. Population that researched all HIV/AIDS patients in Rejoso District, with total sampling technique obtained sample amount31 respondents. Independent variable were family support, with dependent variable social response. The instrument used was questionnaire, the result was analyzed using Spearman rank test with $\alpha=0,05$. Result : The results showed that most of respondents had family support in enough category, amount 19 respondents $(61,3 \%)$ and almost half of respondent had social response in maladaptif category, amount 14 respondent $(45,2 \%)$. The result of analysis showed that $\mathrm{p}$-value $=0,000 \leq \alpha=0,05$ so $\mathrm{H} 0$ rejected and $\mathrm{H} 1$ accepted which means there is correlation of family support with social response of HIV/AIDS patients in Rejoso District Nganjuk Citywith association in the strong category $(\mathrm{r}=0.672)$. Conclusions : The results of this study indicate the higher the family support the better the respondent's social response. Family support in the moderate category has not been able to make HIV / AIDS patients feel that they are loved, valued or noticed so that because of the high social pressure on individuals with HIV/AIDS in the community. It triggers the patient's social response in the maladapatif category
\end{abstract}

Keywords: Family support, Social Response Individual, HIV/AIDS Patients.

\section{PENDAHULUAN}

Wolcott, (2005) dalam Pequegnat

\& Bell, (2011) mengemukakan bahwa respon negatif pada penderita HIV-AIDS menghadapi situasi hidup dimana mereka sering menghadapi sendiri kondisinya tanpa dukungan dari teman dan keluarga yang memberi dampak kecemasan, depresi, rasa bersalah dan pemikiran atau perilaku bunuh diri. Kurangnya dukungan keluarga berdampak pada respon sosial individu pasien tersebut. Respon sosial yang positif dapat mendukung proses pengobatan sehingga progresivitas penyakit setidaknya dapat dihambat dan umur harapan hidup pasien HIV-AIDS lebih panjang. Pasien HIV/AIDS di Kecamatan Rejoso Kabupaten Nganjuk kebanyakan menutup diri dengan sekitar dan cenderung introvert sehingga mudah putus asa akan keadaan yang dialami.

\section{World Health Orgnanization} (WHO) pada tahun 2015 mempublikasikan jumlah penderita AIDS seluruh dunia yang tercatat mencapai 62,11 juta orang dan 
jumlah penderita yang tidak tercatat diperkirakan 2 kali lipatnya. Kementerian Kesehatan Republik Indonesia melaporkan bahwa dari tahun 2015 jumlah kasus AIDS baru yang dilaporkan adalah 2.001 kasus dari 59 kabupaten/kota di 19 propinsi. Dimana ratio kasus AIDS antara laki-laki dan perempuan adalah $2: 1$. Cara penularan kasus AIDS baru yang dilaporkan melalui heteroseksual (76,3\%), IDU (16,3\%), Perinatal (4,7\%) dan LSL (2,2\%). Proporsi kasus AIDS tertinggi dilaporkan pada kelompok umur 20-29 tahun (36,4\%), disusul kelompok umur 30-39 tahun (34,5\%) dan kelompok umur 40-49 tahun (13,3\%). Tahun 2014 dari data P2MK Dinas Kesehatan provinsi Jawa Timur jumlah penderita HIV/AIDS yang terdeteksi adalah 3.587 orang. Berdasarkan data dari Dinas Kesehatan Kabupaten Nganjuk diketahui jumlah pasien HIV/AIDS dari tahun 2002 hingga April 2017 berjumlah 887 pasien, sedangkan untuk wilayah Kecamatan Rejoso jumlah pasien HIV/AIDS dari tahun 2002-2016 berjumlah 32 pasien dan pada tahun 2017 hingga bulan April terdapat 42 pasien HIV/AIDS.

Tujuan dari Penelitian ini yaitu Mengidentifikasi dukungan keluarga pasien HIV/AIDS dan Respon Sosial individu pasien HIV/AIDS di Wilayah Kecamatan Rejoso Kabupaten Nganjuk serta Menganalisis hubungan dukungan keluarga dengan respon sosial individu pasien HIV/AIDS di Wilayah Kecamatan

Rejoso Kabupaten Nganjuk

\section{METODE}

Metode penelitian yang digunakan dalam penelitian adalah penelitian korelasi, yaitu penelitian yang bertujuan untuk mengetahui hubungan dua variabel atau lebih dengan proses pengambilan data yang hanya dilakukan sekali untuk masingmasing variabel penelitian (Notoatmodjo, 2010). Pendekatan yang dipergunakan adalah cross sectional yaitu penelitian yang variabel bebas dan variabelnya terikatnya diukur secara bersamaan dan dilakukan sesaat atau sekali (Nursalam, 2016).

Teknik pengambilan sampel dalam penelitian ini menggunakan total sampling yaitu mengambil sampel dari seluruh anggota populasi (Nursalam, 2016). Kriteria Inklusi yaitu jumlah seluruh sampel yang akan diteliti berjumlah 42 orang sedangkan Kriteria Ekslusi ternyata hanya 31 orang dikarenakan 11 orang meninggal.

Dalam penelitian ini variabel penelitian terdiri dari 1. Variabel Independent / Variabel Bebas (X) yaitu Dukungan keluarga sedangkan Variabel Dependent / Variabel terikat (Y) yaitu Respon Sosial Individu.

Analisa yang digunakan yaitu jika $p$ value $\leq \alpha(0,05)$ maka $\mathrm{H} 0$ ditolak dan $\mathrm{H} 1$ diterima yang berarti ada hubungan dukungan keluarga dengan respon sosial 
individu pasien HIV/AIDS di Wilayah Kecamatan Rejoso Kabupaten Nganjuk sedangkan Jika $p$-value $>\alpha(0,05)$ maka H0 diterima dan $\mathrm{H} 1$ ditolak yang berarti tidak ada hubungan dukungan keluarga dengan respon sosial individu pasien HIV/AIDS di Wilayah Kecamatan Rejoso Kabupaten Nganjuk.

\section{HASIL PENELITIAN}

Hasil penelitian ini yaitu ada Hubungan Dukungan Keluarga dengan respon sosial individu pasien HIV/AIDS di Wilayah Kecamatan Rejoso Kabupaten Nganjuk

Tabel 1 Distribusi Frekuensi Hubungan Dukungan Keluarga dengan respon sosial individu pasien HIV/AIDS di Wilayah Kecamatan Rejoso Kabupaten Nganjuk

\begin{tabular}{|c|c|c|c|c|c|c|c|c|}
\hline \multirow{3}{*}{$\begin{array}{c}\text { Dukungan } \\
\text { Keluarga }\end{array}$} & \multicolumn{6}{|c|}{ Respon Sosial Individu } & \multirow{2}{*}{\multicolumn{2}{|c|}{ Total }} \\
\hline & \multicolumn{2}{|c|}{ Maladaptif } & \multicolumn{2}{|c|}{$\begin{array}{l}\text { Antara adaptif- } \\
\text { maladaptif }\end{array}$} & \multicolumn{2}{|c|}{ Adaptif } & & \\
\hline & $f$ & $\%$ & $f$ & $\%$ & $f$ & $\%$ & $\Sigma$ & $\%$ \\
\hline Baik & 0 & 0 & 5 & 16.1 & 4 & 12.9 & 9 & 29.0 \\
\hline Cukup & 11 & 35.5 & 7 & 22.6 & 1 & 3.2 & 19 & 61.3 \\
\hline Kurang & 3 & 9.7 & 0 & 0 & 0 & 0 & 3 & 9.7 \\
\hline \multirow[t]{2}{*}{ Total } & 14 & 45.2 & 12 & 38.7 & 5 & 16.1 & 31 & $100.0 \%$ \\
\hline & \multicolumn{4}{|c|}{ P-Value $=0,000 \leq(\alpha)=0,05$} & \multicolumn{2}{|c|}{$r=0,672$} & & \\
\hline
\end{tabular}

Berdasarkan tabel 1 diketahui bahwa dukungan keluarga cukup memiliki respon sosial individu dalam kategori maladaptif, yaitu 11 responden (35,5\%). Hasil analisis statistik yang dilakukan menggunakan Spearman Rank diketahui probabilitas $p$ value $=0,000 \leq(\alpha)=0,05$. berarti ada hubungan dukungan keluarga dengan respon sosial individu pasien HIV/AIDS di Wilayah Kecamatan Rejoso Kabupaten Nganjuk dengan keeratan hubungan dalam kategori kuat $(r=0,672)$.

\section{PEMBAHASAN}

\section{Dukungan Keluarga Pada Pasien HIV/AIDS di Wilayah Kecamatan} Rejoso Kabupaten Nganjuk
Dukungan Keluarga pasien HIV/AIDS di Wilayah Kecamatan Rejoso Kabupaten Nganjuk diketahui bahwa sebagian besar dari responden mendapatkan dukungan keluarga dalam kategori cukup, yaitu 19 responden $(61,3 \%)$.

Hasil penelitian menunjukkan sebagian besar responden penelitian pasien HIV/AIDS di Wilayah Kecamatan Rejoso Kabupaten Nganjuk mendapatkan dukungan keluarga dalam kategori cukup. Sebagian besar responden yang mendapatkan dukungan keluarga dalam kategori cukup menjadi malas untuk berobat sehingga dapat menyebabkan terjadinya permasalahan khususnya 
terjadinya penurunan daya tahan tubuh dan beresiko penularan antar anggota keluarga. Adapun penyebab masih belum maksimalnya dukungan yang diberikan oleh keluarga dapat dipicu oleh perasaan takut tertular virus HIV serta adanya anggapan bahwa pasien tidak memiliki harapan untuk sembuh sehingga selain memicu kurangnya dukungan yang diberikan juga membentuk timbulnya diskriminasi. Bentuk diskriminasi dalam keluarga misalnya dengan dikucilkan, ditempatkan dalam ruang atau rumah terpisah

\section{Respon Sosial Individu Pasien HIV/AIDS di Wilayah Kecamatan Rejoso Kabupaten Nganjuk}

Respon Sosial individu pasien HIV/AIDS di Wilayah Kecamatan Rejoso Kabupaten Nganjuk diketahui bahwa hampir setengah dari responden memiliki respon sosial dalam kategori maladaptif, yaitu 14 responden $(45,2 \%)$.

Hasil penelitian menunjukkan sebagian besar responden memiliki respon maladaptif. Adapun respon yang banyak dilakukan penderita adalah penderita HIV cenderung merahasiakan status HIV dari keluarga dan masyarakat, hal ini dikarenakan mereka tidak ingin kehilangan sumber kasih sayang, perhatian dan kebutuhan untuk diakui. Keputusan untuk belum berani membuka status sepenuhnya pada umumnya dilatar belakangi oleh beban yang dirasakan responden serta dampaknya juga akan berimbas pada keluarga besar. Respon sosial maladaptif yang dilakukan penderita HIV sangat mempengaruhi kondisi kesehatan mereka, seperti responden akan semakin menutup diri dan tidak lagi berusaha untuk mendapatkan dukungan-dukungan baik dukungan pengobatan maupun dukungan dari kelompok sosial sehingga kondisi kesehatannya semakin tidak terpantau yang pada akhirnya memperkecil harapan penderita HIV untuk sembuh

\section{Hubungan Dukungan Keluarga} Dengan respon sosial individu pasien HIV/AIDS di Wilayah Kecamatan

\section{Rejoso Kabupaten Nganjuk}

Berdasarkan tabulasi silang diketahui bahwa dukungan keluarga cukup memiliki respon sosial dalam kategori maladaptif, yaitu 11 responden $(35,5 \%)$. Hasil analisis statistik yang dilakukan menggunakan Spearman Rank diketahui probabilitas $p$-value $=0,000$ pada taraf signifikan $(\alpha)=0,05$. Karena $p$-value $\leq \alpha$ maka dapat disimpulkan bahwa ada hubungan dukungan keluarga dengan respon sosial individu pasien HIV/AIDS di Wilayah Kecamatan Rejoso Kabupaten Nganjuk $(r=0,672)$.

Hasil penelitian menunjukkan bahwa terdapat hubungan yang signifikan 
antara dukungan keluarga dengan respon sosial penderita HI/AIDS. Adanya dukungan sosial dari keluarga akan memberi pengalaman pada individu bahwa dirinya dicintai, dihargai, dan diperhatikan. Perhatian dan dukungan dari orang lain akan menumbuhkan harapan untuk hidup lebih lama, sekaligus dapat mengurangi kecemasan individu. Sebaliknya jika dukungan yang diberikan kurang akan menjadikan individu merasa tidak berharga dan terisolasi. Dukungan keluarga sangat diperlukan oleh ODHA agar manajemen psikososial pasien menjadi baik. Dukungan emosional dari keluarga merupakan dukungan yang paling dibutuhkan responden dalam menghadapi penyakit HIV/AIDS yang diderita. Adapun bentuk dukungan emosional yang dibutuhkan pasien berupa perhatian, semangat/ support, kasih sayang, kedamaian. Responden membutuhkan perhatian terhadap konsumsi ARV serta kondisi kesehatannya. sehingga dorongan keluarga akan sangat membantu pe- ningkatan harapan dan kualitas hidupnya. Dukungan berupa perhatian dari keluarga diharapkandapat menunjukkan bahwa keluarga masih peduli dan menganggap pasien merupakan bagian dari keluarga, serta mencintainya walaupun sa|at ini menderita penyakit HIV/AIDS. Defares (2014)

\section{KESIMPULAN}

Sebagian besar dari responden memiliki dukungan keluarga dalam kategori cukup, yaitu 19 responden $(61,3 \%)$. Hampir setengah dari responden memiliki respon sosial dalam kategori maladaptif, yaitu 14 responden $(45,2 \%)$. Ada hubungan dukungan keluarga dengan respon sosial individu pasien HIV/AIDS di Wilayah Kecamatan Rejoso Kabupaten Nganjuk dengan $p$-value $=0,000 \leq \alpha=0,05$ dengan nilai $r=0,672$.

\section{DAFTAR PUSTAKA}

Notoatmodjo, 2010. Metodologi Penelitian Kesehatan. Jakarta : PT Rineka Cipta.

Nursalam, 2016. Manajemen Keperawatan: Aplikasi Dalam Praktek Keperawatan Keperawatan Profesional. Edisi 2. Jakarta : Salemba Medika.

Defares, 2014. The Dutch Eating Behavior Questionnaire (DEBQ) for Assessment of Restrained, Emotional, and External Eating Behavior. International lournat of Eating Disorders

Pequegnat, W., Bell, C., (2011). Family and HIV/AIDS: Cultural and contextualissues in prevention and treatment. council Inc: the institute Juvenil Research Departement of Psychiatry, school of medicine University of illionis Chicago, il, USA 